\title{
Evaluation of Knowledge and Attitude Regarding HIV/AIDS among Adolescents of Varanasi
}

\author{
Narendra Kumar Sharma ${ }^{1}$ \\ ${ }^{1}$ Professor, Department of Community Medicine, Heritage Institute of Medical Sciences, Varanasi, Uttar Pradesh, India.
}

\section{Abstract}

Background: Acquired Immune Deficiency Syndrome (AIDS) is a well-known major health problem particularly in the developing countries.1 AIDS causes devastation to human life and destroys communities and takes away their hope.2The disease results in impairment of the human immune system and allows the emergence of many kinds of opportunistic infections. Subjects and Methods: A total of 150 adolescents (75-boys and 75-girls) of 13-20 years age group were randomly selected from a school in Varanasi. Simple Random sampling technique was adopted for selection of adolescents for achieving the desired sample size. Results: The study was conducted on 150 adolescents of which 75 were males and 75 females. Among these 133 study participants have knowledge about HIV/AIDS, 124 have knowledge regarding modes of transmission and 89 have knowledge regarding modes of prevention. Among the 133 adolescents, majority of adolescents $87.21 \%$ reported that the source of knowledge was electronic media. Conclusion: Burden of HIV/AIDS in the adolescent age group is high in most of the developing countries and in India as well. In the present study, though the study population is aware of the disease HIV/AIDS, but complete knowledge about the disease, its modes of spread and protective measures is not satisfactory. Several misconceptions about the disease do exist amongst the study population.

Keywords: Young People, HIV/AIDS Knowledge and Attitudes.

Corresponding Author: Dr. Narendra Kumar Sharma, Professor, Department of Community Medicine, Heritage Institute of Medical Sciences, Varanasi, Uttar Pradesh, India.

Received: January 2019

Accepted: March 2019

\section{Introduction}

Acquired Immune Deficiency Syndrome (AIDS) is a wellknown major health problem particularly in the developing countries. $^{[1]}$ AIDS causes devastation to human life and destroys communities and takes away their hope. ${ }^{[2]}$ The disease results in impairment of the human immune system and allows the emergence of many kinds of opportunistic infections. The morbid process that leads to AIDS is HIV infection, and it is the first developmental stage of the disease. HIV attacks certain cells of the immune system and destroys them after entering the human host. AIDS, the disease without borders, has already assumed pandemic proportions. India has at least 3.86 million HIV positive patients and 12,000 fullblown AIDS cases have already been reported. ${ }^{[3]}$ The disease is mainly a problem of the young adults with more than 40 percent of the patients under 25 years of age.Adolescence is a period of great physical, mental and emotional turmoil, and the teenagers, in search of their identity, very often start experimenting with intravenous drugs or sex, both making them vulnerable to contracting HIV. Many adolescents are less likely to be aware of HIV/AIDS and the modes of its spread. Since prevention is the key to AIDS control, empowerment of youth with knowledge about high-risk behaviour and its ominous relation with $\mathrm{HIV}$ is a most effective tool to contain the pandemic. Planning an appropriate HIV awareness programme for a specific target group must be relevant to its needs, and can be designed only after determining the existing knowledge, attitude, belief and practice pattern of that particular group. A number of KABP studies conducted in different parts of India reveal widespread ignorance and misconceptions among this vulnerable age group. No such assessment has ever been attempted in the Purvanchal region of the state of Uttar Pradesh.Aim of this present study is an attempt to understand social phenomena i.e. awareness and attitude of HIV/AIDS correlates among adolescents of Varanasi.

\section{Subjects and Methods}

The present study was conducted in Department of Community Medicine, Heritage Institute of Medical Sciences, Varanasi during the period from January to March 2016. A total of 150 adolescents (75-boys and 75-girls) of 13-20 years age group were randomly selected from a school in Varanasi under the jurisdiction of Urban Health Training Centre (UHTC) of the Institute. Simple Random sampling technique was adopted for selection of adolescents for achieving the desired sample size. The information was collected by personal in depth interview of adolescent boys and girls in predesigned, pretested questionnaire and 
appropriate statistical test was applied. Data were entered on and analyzed using Microsoft Excel spread sheet. Descriptive statistics were used and results were expressed as proportions.

\section{Results\&Discussion}

The study was conducted on 150 adolescents of which 75 were males and 75 females. Among these, 133 study participants have knowledge about HIV/AIDS, 124 have knowledge regarding modes of transmission and 89 have knowledge regarding modes of prevention. Among the 133 adolescents, majority of adolescents $87.21 \%$ reported that the source of knowledge was electronic media. Next important source of knowledge was print media. Lal P et al (2005) conducted study of awareness among senior secondary school children in Delhi and reported approximately similar findings as $79.6 \%$ students mentioned the television and radio were the main source of information. ${ }^{[4]}$ Similar findings were observed by Amalraj Edwin and Poddar et al/ ${ }^{[5,6]}$ This is comparable to Delhi study where majority of the students had heard about HIV/AIDS from television and radio.About two thirds of participants were aware that HIV/AIDS is transmitted by sexual contact, whereas only $31.4 \%$ have knowledge that infected needle and syringes can transmit the disease.Sunder M. et al. ${ }^{[7]}$ (1997) reported finding similar to present study, as 81 percent of respondents in his study were aware about sexual contact as a route of transmission of disease. Malleshappa et al. ${ }^{[8]}$ (2008) reported similar findings that $69.2 \%$ participants were aware that disease was transmitted by unsafe sex.

Table 1: Shows the source of knowledge of HIV/AIDS.

\begin{tabular}{|c|c|c|c|}
\hline Variables & $\begin{array}{l}\text { Male (\%) } \\
\text { N=75 }\end{array}$ & $\begin{array}{l}\text { Female }(\%) \\
N=75\end{array}$ & $\begin{array}{l}\text { Total (\%) } \\
\text { N=150 }\end{array}$ \\
\hline \multicolumn{4}{|l|}{ Sources of Knowledge } \\
\hline & $N=69$ & $N=64$ & $\mathrm{~N}=133$ \\
\hline $\begin{array}{l}\text { Print media (News } \\
\text { paper, magazine, } \\
\text { books) }\end{array}$ & $62(89.8 \%)$ & $54(84.3 \%)$ & $116(87.21 \%)$ \\
\hline $\begin{array}{l}\text { Electronic media } \\
\text { (T.V./Radio) }\end{array}$ & $21(30.4 \%)$ & $18(28 \%)$ & $39(29.3 \%)$ \\
\hline Social circle & $17(24.6 \%)$ & $13(20.3 \%)$ & $30(22.5 \%)$ \\
\hline \multicolumn{4}{|l|}{ Modes of Transmission } \\
\hline & $\mathrm{N}=65$ & $\mathrm{~N}=59$ & $\mathrm{~N}=124$ \\
\hline Sexual contact & $51(78.4 \%)$ & $41(69.5 \%)$ & $92(74.2 \%)$ \\
\hline $\begin{array}{l}\text { Infected needle\& } \\
\text { Syringe }\end{array}$ & $16(24 \%)$ & $23(38.9 \%)$ & $39(31.4 \%)$ \\
\hline $\begin{array}{l}\text { Infected blood } \\
\text { Transfusion }\end{array}$ & $35(53.3 \%)$ & $29(49.15 \%)$ & $64(51.6 \%)$ \\
\hline \multicolumn{4}{|l|}{ Modes of Prevention } \\
\hline & $\mathrm{N}=48$ & $\mathrm{~N}=41$ & $\mathrm{~N}=89$ \\
\hline $\begin{array}{l}\text { Safe sex(Use of } \\
\text { condom) }\end{array}$ & $40(83.3 \%)$ & $24(58.5 \%)$ & $64(71.9 \%)$ \\
\hline One faithful life partner & $19(39.6 \%)$ & $13(31.7 \%)$ & $32(35.9 \%)$ \\
\hline $\begin{array}{l}\text { New/ boiled needle \& } \\
\text { syringes }\end{array}$ & $23(47.9 \%)$ & $16(39.02 \%)$ & $39(43.8 \%)$ \\
\hline Tested blood & $20(41.6 \%)$ & $12(29.6 \%)$ & $32(35.9 \%)$ \\
\hline
\end{tabular}

About various modes of prevention $71.9 \%$ adolescents opined safe sex (use of condom), whereas only $35.9 \%$ adolescents said tested blood as a mode of prevention.
Srivastava A et al (2011). ${ }^{[9]}$ also reported similar findings as $78.6 \%$ respondents had knowledge about condom as means of protection. Francis $\mathrm{P}$ T et al, ${ }^{[10]}$ also observed that $79 \%$ students thought that use of condom decreases the risk of getting AIDS. Sunder $M$ et al, ${ }^{[11]}$ conducted a survey in 7 urban colleges and found that $59 \%$ of females indicating that HIV transmission could be prevented by using condom.Regarding boiled/ new needle and syringes $43.8 \%$ said yes, while one faithful life partner was reported by $35.9 \%$. Almost similar finding were reported by Shailesh J. Kore (2002), ${ }^{[12]}$ and PatilSharmila et al. (2001), ${ }^{[13]}$ as 42.25 percent and 37.5 percent of the respondents respectively said that having one faithful partner could prevent disease.

Table 2: Shows the Attitude of adolescents towards the HIV/AIDS patient

\begin{tabular}{|l|l|l|l|l|}
\hline Attitude & $\begin{array}{l}\text { Male (\%) } \\
\mathbf{N = 7 5 ( \% )}\end{array}$ & $\begin{array}{l}\text { Female } \\
(\boldsymbol{\%}) \mathbf{N = 7 5 ( \% )}\end{array}$ & $\begin{array}{l}\text { Total (\%) } \\
\mathbf{N = 1 5 0}(\%)\end{array}$ & $\begin{array}{l}\mathbf{P} \\
\text { value }\end{array}$ \\
\hline $\begin{array}{l}\text { Will have } \\
\text { sympathy }\end{array}$ & $62(82.6 \%)$ & $51(68.0 \%)$ & $113(75.3 \%)$ & 0.05 \\
\hline $\begin{array}{l}\text { Allow to read } \\
\text { in the same } \\
\text { class }\end{array}$ & $40(53.3 \%)$ & $42(56.0 \%)$ & $82(54.6 \%)$ & 0.37 \\
\hline $\begin{array}{l}\text { Allow to live } \\
\text { in the family }\end{array}$ & $35(46.6 \%)$ & $32(42.6 \%)$ & $67(44.6 \%)$ & 0.27 \\
\hline $\begin{array}{l}\text { Allow to use } \\
\text { daily routine } \\
\text { thing }\end{array}$ & $28(37.3 \%)$ & $24(32.0 \%)$ & $52(34.6 \%)$ & 0.53 \\
\hline $\begin{array}{l}\text { HIV test } \\
\text { before the } \\
\text { marriage }\end{array}$ & $54(72.0 \%)$ & $41(54.6 \%)$ & $95(63.3 \%)$ & 0.001 \\
\hline $\begin{array}{l}\text { Assurance of } \\
\text { new/ } \\
\text { sterilized } \\
\text { syringe, } \\
\text { needles }\end{array}$ & $65(86.6 \%)$ & $57(76.0 \%)$ & $122(81.3 \%)$ & 0.07 \\
\hline
\end{tabular}

Table 2 shows that out of total 150 adolescents, regarding the attitude about AIDS patient majority (75.3\%) of adolescents, reported to have sympathy. Majority (54.6\%) of adolescents agreed to read with HIV/AIDS cases. However, $44.6 \%$ of adolescents, said that they would not allow the HIV patient to live in the family, and almost one third of adolescents (34.6\%) said that they would not allow using their daily routine things by the HIV patients. Regarding the test of HIV before the marriage, $63.3 \%$ said yes; and regarding the injectables, before taking injection confirmation of new/sterilized needle and syringe, majority of adolescents $81.3 \%$ reported yes.

Table 3: Shows the Attitude of adolescents towards HIV topic and high-risk behavior

\begin{tabular}{|l|l|l|l|l|}
\hline Opinion & $\begin{array}{l}\text { Male (\%) } \\
\mathbf{N = 7 5 ( \% )}\end{array}$ & $\begin{array}{l}\text { Female } \\
(\%) \\
\mathbf{N = 7 5 ( \% )}\end{array}$ & $\begin{array}{l}\text { Total (\%) } \\
\mathbf{N = 1 5 0}(\%)\end{array}$ & $\begin{array}{l}\mathbf{P} \\
\text { value }\end{array}$ \\
\hline $\begin{array}{l}\text { Agreed for } \\
\text { introduction of } \\
\text { HIV topic }\end{array}$ & $66(88.0 \%)$ & $45(60.0 \%)$ & $111(74.0 \%)$ & 0.01 \\
\hline $\begin{array}{l}\text { Sexual contact } \\
\text { with friend } \\
\text { before marriage } \\
\text { can be made }\end{array}$ & $7(9.3 \%)$ & $3(4.0 \%)$ & $10(6.6 \%)$ & 0.07 \\
\hline Sexual contact & $6(8.0 \%)$ & $1(1.3 \%)$ & $7(4.6 \%)$ & 0.016 \\
\hline
\end{tabular}




\begin{tabular}{|l|l|l|l|l|}
\hline $\begin{array}{l}\text { can be made } \\
\text { with a person } \\
\text { having multiple } \\
\text { sex partner }\end{array}$ & & & & \\
\hline
\end{tabular}

Table 3 shows that overall $74 \%$ adolescents in which $88 \%$ of males and $60 \%$ of females were agreed for the introduction of HIV topic in the course curriculum (p 0.01). Regarding the attitude towards sexual contact before marriage the majority $63.3 \%$ adolescents said no. Regarding the multiple partners sexuality the majority of adolescents (93\%) reported no (98.7\% of females and $92.0 \%$ of males). The difference between male and female was found statistically significant $(\mathrm{p}<.016)$. Regarding the attitude toward people living with HIV, results of the present study shows that attitude of majority of the study subjects toward people living with HIV is discriminatory. Unwillingness to accept HIV positive cases could be due to misconceptions about the disease and not many educational programs are in place which are targeted toward adolescent and youth population. Singh A et al in their study also reported that their subjects were having a discriminatory attitude to some extent toward HIV infected people. ${ }^{[14]}$

\section{Conclusion}

In conclusion, Burden of HIV/AIDS in the adolescent age group is high in most of the developing countries and in India as well. In the present study, though the study population is aware of the disease HIV/AIDS, but complete knowledge about the disease, its modes of spread and protective measures is not satisfactory. Several misconceptions about the disease do exist amongst the study population. There should be classroom based education programme on HIV/AIDS and STDs and the class teacher should be properly trained for educating the students effectively in modes of transmission and methods of prevention of HIV/AIDS.

\section{References}

1. Chatterjee, C., Bauer, C., Ram, R., Ohar, G., Sandhukukhan, S., and Dan, A. A Study of Awareness of Aids among School Students and Teachers of Higher Secondary Schools in North Calcutta. Indian Journal of Public Health. 2001. 45 (1) 27-30.

2. Ministry of Education, 2003: HIV/AIDS Guidelines for Educators (Ministry of Education, Lusaka).

3. RAMLINGASWAMI V. (2000): Frontline Messages: HIV/AIDS in India; Round Table Conference, Series No. 6, Ranbaxy Science Foundation, New Delhi, p. 6.

4. Lal P, Nath A, Badhan S, Ingle GK. A study ofawareness about HIV/AIDS among senior secondary school children of Delhi. Indian Journal of Community Medicine 2008; 33 (3):1

5. Edwin RA, Nirimala C, Sunithi S, Ganapathy, Raja PS, First year medical students AIDS Knowledge and Attitude. IJCM,1995 20(4) 52-53.

6. Poddar AK PoddarSaha D, Mandal RN: Perception about AIDS among residents of Calcutta slum IJPH 1996, 40(1) 15-17.

7. Sunder M, Kavita J, Mathai LM, Nath CM. Knowledge of AIDS among student population in Bangalore city: HIV/AIDS Research in India, NACO, MHFW, Govt. of India, 236-240, 1997.

8. Malleshappa K, Krishna S, Kumarshashi. Awareness and attitude of youth towards HIV/AIDS in rural southern India. Biomedical Rearch 2012: 23(2): 241-246.

9. Kore SJ, Pandole A, Nemade Y, Putharaya S, Ambiye VR. Attitude, knowledge, beliefs about HIV/AIDS in college going Adolescents from the different colleges. Bombay Hospital Journal;2002:146.

10. Srivastava A, Mahmood SE, Mishra P, Shrotriya VP, Shaifali I. Adolescence awareness: a better tool to combat HIV/AIDS. National Journal of Community Medicine 2011;2 (1):86-90.

11. Francis P T, Gill JS, Chowdhury: Knowledge, beliefs and attitudesregardindg AIDS/STDS and human sexuality among senior secondary students on Delhi, HIV/AIDS research in India 1992, 162165.

12. Sunder L, Malik JS, Singh VBM, Punia MS, Jam R B: General population survey in rural area to generate prevention indicators for HIV/AIDS control, Indian J of community medicine 1998:23(2)5055 .

13. Sharmila P, Chaturvedi R, Malkar MB: Cross sectional study in an urban slum community in Mumbai; Department of Preventive and Social Medicine, Seth GoverdhandasSunderdas Medical College and KEM Hospital, Parel, Mumbai(2001).

14. Singh A, Jain S. Awareness of HIV/AIDS among school adolescents in Banaskantha district of Gujarat. Health and Population: Perspectives. 2009; 32(2):59-65.

Copyright: (C) the author(s), 2019. It is an open-access article distributed under the terms of the Creative Commons Attribution License (CC BY 4.0), which permits authors to retain ownership of the copyright for their content, and allow anyone to download, reuse, reprint, modify, distribute and/or copy the content as long as the original authors and source are cited.

How to cite this article: Sharma NK. Evaluation of Knowledge and Attitude Regarding HIV/AIDS among Adolescents of Varanasi. Asian J. Med. Res. 2019;8(1):CM16-CM18.

DOI: dx.doi.org/10.21276/ajmr.2019.8.1.CM3

Source of Support: Nil, Conflict of Interest: None declared. 